\title{
Extending the analysis of urban land conflict: An example from Johannesburg
}

\section{Abstract}

Social conflict can be mobilised to achieve progressive and/or regressive change. Focusing on urban land conflicts that relate to property rights, I examine how a common way of understanding this type of urban land conflict has an effect of glossing over conflict that emerges because of the property rights themselves as well as only legitimating certain types of conflict as worthy of activism and scholarly engagement. Using the example of Thokoza, a largely residential area outside of Johannesburg, I juxtapose two different analyses in order to clarify the additional value of also thinking about conflict caused by property rights themselves that emerges from the second analysis.

Keywords: property rights, urban development, South Africa, urban land conflict

\section{Introduction}

This article adds to efforts to explain, and engage with, urban land conflicts. Activists, policy makers and researchers have long recognised that social conflict can be engaged with to achieve progressive and/or regressive social change. In many cities in the global South, as well as in my own experience, urban activists and scholars have grappled with how to engage with urban land conflicts in ways that promote progressive change in favour of poor and marginalised groups and resist regressive changes.

I work with a broad view of conflict ranging from periodic violence to verbal confrontations that make up the "many forms of low-level instability ... [which are] 
difficult to categorise but increasingly important in the context of rapid urbanisation" (Beall et al., 2011: 5) (Comissão Pastoral da Terra 1996 in Hui and Bao, 2013: 374). What I am particularly interested in is how specific understandings of urban land conflict legitimate certain kinds of conflict as worthy of engagement by activists and scholars. This leaves other 'conflicts' as either unrecognised or unable to be engaged with to achieve the desired social changes. The danger is, that in such contexts, activists and scholars are hampered in understanding whether such conflict offers the potential for progressive change or how it might be used to resist regressive change.

There are many types of urban land conflicts. Some are linked to urban processes of that revalue or govern land (Kombe, 2010). Others might relate to expressions of ethnicity and experiences of corruption (Obala and Mattingly, 2013). These are important types of conflict, but what I have in mind here are urban land conflicts common to many cities in the global South that relate to claims to, and competition for, property rights to urban land.

Property rights to urban land are becoming increasingly important in relation to urban development and the ways that cities function. First, as competition for urban land increases, the clarification of property rights has become more important as land is commodified (Kombe, 2005; Kombe, 2010; Rakodi and Leduka, 2004) and within and across plural legal orders (Benda-Beckman, 2002; McAuslan, 2005). And second, urban land administration has gained increasing attention in efforts to make property rights more transparent (GLTN, 2012). Focusing on property rights to land then, affords, an important understanding of key forms of urban land conflicts. 
My argument is that when, and where, urban land conflict is primarily understood as a struggle over (already) defined property rights the analysis tends to neglect conflict that occurs because of the contested nature of property rights themselves and validates certain types of conflicts as worthy of engagement over others. The conceptual basis that property rights can be a source of conflict is derived from recognition that property rights are always based on social relations between people in relation to things, in this case land (Blomley, 2004; Macpherson, 1992; Singer, 2000). From this perspective, property rights are relational, constructed, contingent on the social context and continually have to be 'produced'.

There are, therefore, two ways in which conflict is inherent in property rights. First, because social relations are typically unequal, inequality comes to be reflected in the expression and current definition of property rights. Second, one of the main functions of property rights is to reduce the potential for conflict by clarifying the conditions and circumstances under which different parties can use and hold land, hence they are always a reflection of previous conflicts. Property rights in land therefore reflect existing and past conflicts of different kinds, which in turn shape the outcome of current struggles in relation to property rights because the way in which conflicts are imbricated itself creates the potential for conflicts.

I deliberately use the term 'property rights' to refer to both property 'rights' and 'claims'. A distinction is often made between 'property rights' which are formally recognised and enforced by the state and 'claims' which may or may not be recognised by state law; where they are not, they are informal or extra-legal. Rejecting this distinction in conceptual terms, I seek to destabilise the implicit 
hierarchies that exist between (superior) rights and (inferior) claims. My view is more consistent with the understanding of property rights as being based on social relations between people and where a 'right' is a particular type of claim that emerges out of specific networks of agents, institutions, processes and so on. Furthermore, in practice, the vast majority of claims are based on perceived 'rights' (i.e. rights recognised and enforced by and through different networks of institutions, agents, processes and places), so that even 'informal' claims may have elements that are recognised by the state and thus, making the distinctions between rights and claims more difficult to discern. This is different to thinking that distinctions between 'rights' and 'claims' are not important. Clearly, 'rights' enable some people to engage the state and its power to achieve certain ends. But, by seeing 'rights' and 'claims' as both forms of claims does not automatically privilege one of the other and predetermine the outcomes of struggles between those holding property rights and those with 'claims' to land.

In the next section, I outline an example of a common framework that explains conflictual struggles as being over property rights to land and highlight two issues that need to be explored in more depth as a result of this type of analysis. Using an example of Thokoza, a precinct in a largely residential township east of Johannesburg, Section 4 juxtaposes a view of urban land conflict in the area as being over property rights with a view of urban land conflict emerging because of the property rights. I conclude by discussing the added value of complementary analyses of urban land conflict related to property rights in terms of identifying and legitimating new forms of conflict for activists and scholars to engage with. 


\section{Urban land conflicts as struggles over property rights}

In this section, I draw on an example of the type of analysis that frames urban land conflict as struggles over the property rights to land. Using Wehrmann's (2008) framework as an example is useful because it has brought coherence to discussions of land conflict in urban contexts in the global South. It has circulated in academic circles (Hui and Bao, 2013; Lombard, 2012), as well as international organisations focused on land, such as the Food and Agriculture Organisation (FAO), and influential professional bodies such as the International Federation of Surveyors (FIG). I discuss her work in order to consider an example of this type of analysis, acknowledging the danger of over-simplifying a complex framework as well as relying on one scholar's work to represent this type of analysis. This discussion shows how motivations for conflict are related to competing interests rather than the property rights themselves and serves to identify two issues requiring further analysis.

Wehrmann argues that "land conflict can be defined as a social fact in which at least two parties are involved, the roots of which are different interests over the property rights to land: the right to use the land, to manage land, to generate an income from the land, to exclude others from the land, to transfer it and the right to compensation for it" (Wehrmann, 2008: 9). Different "kinds of land" (state, private or common property) are identified and a comprehensive set of categories of conflict is set out (Wehrmann, 2008: 14). Some conflicts, such as those occurring over boundaries, are considered common to all kinds of land. Some, such as expropriation without compensation, are presented as specific to private land, while others, such as the grabbing of public land by state officials, relate only to state land, and conflicts 
relating to collectively owned property arise because there are competing uses for the land.

Given that this type of conceptualisation of land conflict focuses on 'interests', it is not surprising that a key part of the analytical framework is concerned with how to identify interests and what might motivate those interests. It is assumed that conflict is a function of interests and motivations and that these may be pecuniary and/or emotional. For example, Wehrmann identifies five deep causes of land conflicts. In my view, these can be grouped into two. Notably, despite the diversity of causes, none are related to property rights themselves.

In the first group, land conflict has very little to do with land and is instead a proxy for other societal conflicts, which are deeply rooted in historical social inequalities. By far the more important, from the point of view of 'urban land conflict', is the second group, which is comprised of three sets of causes. In these instances, conflicts are motivated by individual interests, which may be driven by the quest for profit maximisation. This motivation, in turn, is driven by deeper factors. First, the search for profit maximisation is "based on emotional and material needs, which ... are a consequence of psychological fears and desires. Therefore, [in this view] psychological phenomena form the basis of land conflicts" (Wehrmann, 2008: 24). In drawing attention to psychological issues, Wehrmann ensures that the dimension of affect is included in the analysis of land conflict (Lombard, 2012).

The second set of deep causes emerges from disjunctures in the institutions like courts and land administration agencies that are designed to keep excessive profiteering in 
check, provide stability and moderate psychological issues. When there is institutional change, she suggests, the prevailing consensus is disturbed. This creates possibilities for conflict and may also weaken the ability of the institutional apparatus to keep social forces in check.

The third set of interdependent causes is contextual, although they are also important for their influence on individual psychologies. "Frame conditions", such as natural disasters leading to migration, may be related to natural population increase, as well as increased commodification of land, institutional instability and poverty - these combine to provoke "strong psychological desires and fears... [and] extreme emotional and material needs" (Wehrmann, 2008: 26-27). These drive people to express their differences over property rights to land through institutions such as courts and land administration agencies and economic processes such as markets.

The use of this type of framework encourages activists and scholars to adopt the view that "preventing land conflicts means simultaneously avoiding institutional deficits, limiting extreme needs for land and reducing opportunities to make excessive economic profit from the land market. This [it is suggested] can be achieved by a combination of correcting institutional weaknesses and introducing good land governance" (Wehrmann, 2008: 91). The assumption is that, while deeper issues will continue to trigger conflict, successful interventions can reduce the number and violence of land-related conflicts.

Notwithstanding the immense value of this type of framework, it is worth pausing to consider where, and how, it encourages activists and scholars to work with conflict. 
There are two implications I want to highlight. First, this type of framework tends to take property rights for granted, because the focus is on the conflicts associated with struggles over the property rights in land that can underpin accumulation and/or personal security. It follows that what is most legitimate is for activists and scholars to work with the relative strengths of the competing parties in order to promote the desired social change of minimising conflict by improving the property rights that disadvantaged groups have access to.

Second, identification of the deepest causes of conflict is based on an assumption of individual desires and fears that too easily map onto individuals holding property rights. However, this is unnecessarily restrictive and takes the focus away the ways in which property rights are the motivator and result of a wide network of interdependent relations. Moreover, the focus on individuals can, perhaps unintentionally, reinforce the dominance of the ownership model of property. In this model, public or state and common property exist, but private property is clearly distinguished from these other forms and ownership is taken almost exclusively to be concerned with individual private property rights (Singer, 2000). A problem with this extremely pervasive view is that private property rights recognised by the state are taken to be settled and ordered, thus the very last place where inherent conflict would be expected to occur (Blomley, 2004).

In the sections that follow, I illustrate the value of adding a perspective that uses property rights as a lens to think through the processes by which property rights are conflictually constituted, thereby influencing current struggles over property rights. I 
draw on research on a small precinct of land in a township in Ekurhuleni Metropolitan Council, immediately to the east of Johannesburg in South Africa.

The original research drawn upon here was conducted in 2007 in three sites in greater Johannesburg (Marx and Rubin, 2008). The three sites (Thokoza, New Doornfontein, and Diepkloof) were selected in order to ensure a spread of different patterns of land uses, property rights and historical processes of development. In each, a precinct (smaller than a neighbourhood but larger than a block) was selected for study, based on the existence of 'iconic' features that assisted the identification and tracing of relevant information in the archival records that were consulted. In this article, findings relevant to urban land conflict are presented. Because of the need to track back and forth across time and to present in-depth analysis, in this article I focus only on Thokoza. It is a largely residential township to the east of Johannesburg, which originated in the 1950s as part of an attempt by the authorities to reduce the increasingly unmanageable densities in existing, poorly serviced townships.

\section{Fig 1 INSERT MAP OF JOHANNESBURG WITH LOCATION OF THOKOZA} ABOUT HERE

The research generated accounts of how people had managed to negotiate access to, and retention of, property rights to land over the years. It was based on 15 in-depth interviews with longstanding land users in Thokoza, 12 interviews with municipal officials who reflected on trends across all three sites and archival work. The data was analysed to identify patterns, both commonalities and differences, which emerged from the different accounts. The following section analyses urban land conflict, first 
in terms of differing interests over property rights to land, and then by identifying conflicts that have arisen because of the property rights themselves.

\section{A precinct in Thokoza}

In some very fundamental ways, conflict about property rights to land is the story of apartheid. At the heart of the apartheid endeavour was the attempt to racially control who could use, manage, generate an income from, exclude others from, or transfer land, ostensibly to reduce inter-racial conflict but also for the benefit of those defined as 'white' (Beningfield, 2006; James, 2007). This created enduring inequalities in the extent of land ownership and ways in which property rights could be held by different groups. Thus, it is not surprising that the history of land in a precinct in a racially defined residential township tells a story of conflict over property rights.

Fig 2. INSERT MAP OF THOKOZA PRECINCT ABOUT HERE

\section{Conflict over property rights}

A brief overview of the precinct's history is useful to illustrate some of the conflicts that emerged from differences over property rights to land. Thokoza - ironically meaning 'place of peace' - was proclaimed a township in 1958-59 by the 'White' Alberton Local Authority, in a renewed attempt to reduce conflict by gaining control over the migrants (mainly Black African men) drawn to the urban employment 
opportunities offered by the wider Johannesburg economy. ${ }^{1}$ Black Africans were forcibly relocated to Thokoza from nearby 'locations', which themselves had been established by other 'White' Local Authorities during failed attempts to control Black African settlement in urban Johannesburg between 1907 and 1910 by forcibly relocating residents of informal settlements around the mines. Overcrowding in officially declared residential areas, leading to the construction of backyard shacks for rent and the emergence of informal settlements, was and continues to be a repeated cycle, because the amount land officially provided for Black African use has been hopelessly inadequate at every stage of the city's history.

Thokoza was purchased as farmland, rezoned for residential use, and proclaimed under the Native (Urban Areas) Consolidation Act of 1945 by the 'White' Alberton local authority. 17,500 plots were laid out in the township and evictees who were allocated a plot were issued with 30-year leases. In addition, between 1960 and 1980, the Madala, Buyafuthi and Umshayzafe hostels were constructed to house 2,500 men attracted to the employment opportunities in the mines and nearby industrial areas. The Alberton Local Authority maintained control over the space in the hostels by requiring prospective residents to apply for a bed and pay for an initial permit. On acceptance, hostel residents paid a monthly rent to the municipal workers, who maintained an office at the hostel entrance. Despite high degrees of municipal surveillance and control, by the $1980 \mathrm{~s}$, the hostel population had risen to 13,000 .

\footnotetext{
${ }^{1}$ Thokoza is now a residential suburb that falls within the metropolitan authority of Ekhuruleni. Ekhuruleni Metro is immediately east of the Johannesburg Metropolitan Authority and was formed in 2000 through the amalgamation of nine local governments. Racially based local government structures such as the Thokoza Town Council had been established in 1983 but were disbanded in 1987.
} 
In defiance of Apartheid regulations, the population living on residential plots in Thokoza doubled between 1970 and 1975 (from 27,673 to 47,900 people). However, almost no new land was made available and only 38 new houses were built in the 1970s. The consequence of the local authority's failure to demarcate additional plots despite the growing Black African population, which continued to increase in the 1980s, meant that people moved into shacks constructed in the backyards of existing houses and also established informal settlements. By 1982, it was calculated that, on average, there were two backyard shacks on each of the 17,500 plots. About ten years later, the number of backyard shacks was calculated to have risen to 65,000 . In the initial stages, the Alberton Local Authority forced the backyard shack dwellers to pay a levy, with the intention of dissuading settlement. However, a combination of a growing economy and the dire lack of any other housing opportunities meant that very few tenants left (Sapire, 1992). The (undoubtedly unintended) consequence of the levy was to implicitly sanction the practice of backyard shack rental. In addition, in nearby townships adjacent 'White' Local Authorities began large-scale forced evictions of informal settlements of people struggling to gain a legitimate foothold in the urban economy. For example, in the first six months of 1983, over 68,000 informal dwellers lost their homes, a significant proportion of whom were 'repatriated' to the homelands. The Alberton Local Authority attempted to carry out similar large-scale evictions in Thokoza in 1984, but found it impossible to ignore the outcry that followed and the initiative failed.

Between 1981 and 1990, the population of Thokoza grew from 50,719 to 228,000 persons, according to official figures (Bonner and Nieftagodien, 2001; Vermeulen, 1981). The space and minimal infrastructure planned for 17,500 households was 
clearly neither sufficient nor adequately maintained for the growing township. The lack of funding for development of extensions to the residential area was justified by the national government's view that townships should be financially self-sufficient. In order to try and raise some money for development and maintenance, local councils were encouraged to increase the rents paid by occupants of state-supplied dwellings and tariffs for various services. However, this emphasis on increasing revenue from rents and tariffs coincided with a general economic slowdown and in the ensuing hardship, many households could not afford the increases.

At the same time that the national state was forcibly evicting Black Africans from informal settlements and backyard shacks, it was itself establishing the equivalent of informal settlements, leading Sapire (1992) to describe the state's approach to land management as 'schizophrenic'. For example, in 1987, the Thokoza Town Council ${ }^{2}$ established a 'temporary' settlement of 500 households near the Thokoza water tanks, consisting of people forcibly removed from the nearby coal yards. The services provided were so rudimentary that there was little difference between this settlement and typical informal settlements constructed by ordinary people. The area became known as Phola Park as immigrants and residents of backyard shacks started to settle informally in the area. The Thokoza Town Council sanctioned the settlement of the original 500 households but their legal status to the land was unclear (Bremner, 1994). The legal status of the subsequent residents who obtained land by invading and settling informally was even less clear, and thereby creating new struggles over

\footnotetext{
2. Thokoza Town Council had an ambiguous relationship to Alberton Local Authority. Although there were many interconnections due to the historical evolution of the built environments, in many ways it was the national state that exercised greater control of Thokoza Town Council through budgets and legislation.
} 
property rights. By 1988 its population stood at 15,000 and by 1991, it was estimated to be $24,000-30,000$ people, with few toilets and virtually no access to water.

In the early 1990 s, with major political change in the air, the politically conservative Inkhata Freedom Party (IFP) started to build a national identity based on its traditional provincial roots in Kwazulu-Natal amongst the different ethnicities in Johannesburg. In the extremely volatile and violent conditions that ensued, many people were displaced. For example, Respondent 19a, a female long-term township dweller, described how she was dispossessed of her house and fled to a different informal settlement, before moving back to the Phola Park informal settlement. However, Phola Park offered little sanctuary. In 1991, at the height of the fighting, 150 people were killed and hundreds of shacks razed. The civil war in Thokoza (mirrored more broadly in other parts of South Africa) continued throughout 1991 and 1992, aided by a complicit apartheid state, mercenaries from neighbouring countries, who supplied arms and expertise to both sides in the conflict, and both the main political parties, which were intent on using Thokoza to make ideological points about their capacity to represent the urban population in a post-Apartheid scenario.

In 1993, violence intensified around Khumalo Street (see Fig 2), because of the uncertainty engendered by the process of broader political transition. 'Noncombatants' were cleared from Khumalo Street and Zulu warlords took over most of the hostels and many of the houses (Anonymous 2008: pers comm.). ANC supporters responded by 'clearing' the informal settlements of all those identified as having a Zulu ethnicity. The evicted Zulus either relocated to the hostels (with their families) or returned to their rural homes. The latter were replaced by young Zulu men, intent 
on advancing the cause of the IFP and Zulu identity. During the ensuing violence, which gripped Thokoza while the remainder of South Africa celebrated the first free elections, hundreds of people lost their rights to property.

Caught up in this violence was a sustained attempt by an NGO - Planact - to shift the focus away from party political-inspired violence to developmental needs and provision of new land for the people living in Phola Park informal settlement. After stopping and starting due to the wider violence, a participatory project re-commenced in 1992. The project had broad support but was ultimately scuppered by two groups of people with different views of, and relationships to, land. The first group was identified, by the NGO and community development committee, as a loosely affiliated group of young men who lived either in the hostels or in Phola Park, but who considered their current residence to be informal and temporary, as they ultimately intended to return to their rural place of origin. These migrants were interested in saving as much money as possible as quickly as possible. While initially ignoring the project, they came to violently object to any process that would increase the charges they would have to pay.

The second group was comprised of immigrants from Mozambique, a country itself gripped in a long-running civil war, many of whom played an active role in the violence. Their military experience and contacts, which proved invaluable in sustaining the violence in Thokoza, also provided a means of leveraging a plot on which they could settle informally. Mozambican immigrants had initially tended to settle on the periphery of Phola Park. However, housing policy regulations meant that formal property rights were only ever going to be granted to South African citizens. 
Ultimately, the Mozambican residents in the informal settlement would have been evicted, motivating them to oppose the project because they felt that, if they could not hold onto their hard-won gains in Thokoza, they would have nowhere else to go (Baskin, 1993; Bremner, 1994). When members of the Community Development Committee, who were supposed to represent community interests during the upgrading project, were assassinated, the project came to halt.

In conflict over rights to land, therefore, the story of Thokoza demonstrates that in the South African context, a significant element of conflicts may be about gaining what are considered to be the most secure property rights. In 2006, leaseholds in Thokoza were converted to freehold titles under a Regularisation and Transfer of Ownership scheme (Gauteng Provincial Government, 2006). Leaseholders who could prove that they had been paying rent were offered the chance to purchase their land and dwelling. The purchase prices were heavily discounted or occupants were simply declared the owners. As part of this process, households that had lost their plots during the violence of the early 1990s were reinstated as the legitimate owners of the property rights.

I have sketched a very conflictual period in Thokoza's history in which people were deliberately denied certain property rights but partially legitimated in other ways creating the basis for a struggle over property rights. To come back to the type of analysis that comes out of Wehrmann's framework, the struggle is conceived as being over converting an individual's property rights to higher or more secure levels. This is, of course, an important struggle. Poor and marginalised groups can benefit from the security associated with state backed property rights. Moreover, the 'fears and 
desires' that motivate individual psychological and physical forms of security are important and need to be taken seriously, even if they are more difficult to pin down analytically. However, this type of analysis tends to legitimate one form of conflict as worthy of engagement by activists and scholars and does not help explain why urban land conflicts continue to rumble along - even though significant numbers of people have 'higher' more secure property rights.

\section{Property rights as a lens through which to analyse conflict}

In this section, I examine how the different property rights that people hold, use and acquire can themselves contribute to conflicts. I focus on how property rights in Thokoza are the outcome of conflict between different social groups; how nominally similar property rights in different parts of the city are not the same in practice; how property rights in Thokoza are less protected and enforced than in other parts of the city; and how property rights are part of networks that may contain elements that act as lightening rods to other conflicts and hence can never be neutral.

\section{Property rights as the outcome of conflict}

In the 1950s, the Apartheid state allocated Black Africans township plots and houses with leasehold rights, initially for 30 years and later for 99 years. ${ }^{3}$ These were seen as conveying rights inferior to those provided by the freehold property rights freely available to White Africans, but superior to any other right permitted to Black Africans. That is, leasehold property rights were caught up in complex relationships

\footnotetext{
${ }^{3}$. It is important to note that a minute proportion of Black Africans held land under freehold title, mainly on land that was historically owned by religious mission stations. There were such instances in Thokoza.
} 
with other rights. In a pattern that repeated itself time and time again, the Apartheid state used divide-and-rule strategies to create conflicts, weaken opposition and maintain control. For, while a 30-year leasehold was not the same as freehold, it was a good deal better than renting, settling informally or, even worse, relying on customary property rights that were under severe pressure in the overcrowded rural 'homelands'. Thus, despite facing the same forms of general discrimination, different groups of urban Black Africans, all desperately trying to avoid being bundled out to the impoverished homelands, were pitted against each other as the state used property rights to stoke and try to manage racial conflict.

Of course, property rights are also the outcome of many other processes and not just conflict, however embedded and pervasive it might be. It is therefore necessary to consider other elements such as how property rights to land are nominally similar but different in practice.

\section{Property rights as expressions of conflict}

Despite their relative superiority, the leasehold property rights people held in Thokoza were of a lower quality than leasehold rights held (by whites) in other parts of Johannesburg. Thokoza was hastily established to avoid conflict by maintaining law and order and accommodating the Black African population and addressing the inability of the other townships set up between 1950 and 1954 (Katlehong and Vosloorus) to absorb the growing numbers of Black African residents. The latter townships had done little to absorb Black Africans living in suburban backyards and farmlands on the periphery of the city, provide satisfactory facilities and services, or respond adequately to the racist perception of the ever-present threat of racial conflict. 
The provision of more land for Black African housing in the 1950s was, however, not accompanied by budget allocations for the provision of infrastructure and engineering services or the construction of housing. This apartheid-inspired neglect of land development for urban Black Africans led to further conflicts, as the pressures arising from overcrowded living affected both other urban areas and residents. The authorities quickly realised that merely providing land would result in the emergence of environments that were as difficult to police and control as the shack settlements they had just demolished. It became evident that at least a basic level of servicing and housing provision would be necessary to achieve some degree of order.

The dilemma created by the need to provide more land to house Black African urban residents without incurring increased costs or antagonising 'White' local authorities by burdening them with additional costs was addressed by providing for the use of cheap Black African labour to construct dwellings in the townships through the promulgation of the Bantu Building Workers' Act of 1951. The provisions in this Act legalized the training of Black Africans as skilled labour in the construction industry but restricted the places in which skilled workers were permitted work. As a result of these provisions, building costs were significantly reduced. In addition, in order to meet part of the cost of improvements to the land, the Bantu Services Levy Act of 1952 provided for a levy on Black African employees. In this sense then, even though leasehold rights were nominally the same across different racial groups, in effect, those held by Black Africans were impoverished in terms of local authorities' access to finance to improve the quality of land and housing held under the rights. 


\section{Property rights as less protected and enforced}

So far, I have illustrated how property rights were used to create conflict between different groups and how those issued to urban Black Africans by the state were of lower quality than those provided to other groups defined in racial terms. In addition, both leaseholds and rental permits were more weakly protected and enforced than property rights held by whites. White African, and then Black African, local authorities lacked the resources and legitimacy to effectively enforce property rights. Thus Thokoza was 'governed' successively by a number of different 'Boards', 'Councils, 'Administration Boards', 'Community Councils', and 'Black Local Authorities'. These entities had two features in common. First, while provision was made for increased Black African control over local matters, the Apartheid authorities ensured that the local bodies had limited power and autonomy and that control over them could be maintained. Second, the new bodies were increasingly expected to be self-financing. Typically, additional resources could only be generated by raising rents or service charges, which the impoverished residents could not afford to pay. As a result, the local authorities were consistently inadequately resourced and many ran into debt. By 1984, Thokoza Township had accumulated arrears of rent and service charges that amounted to R340,399 and that doubled over the course of the following year to R626,153, partly because a boycott of the Thokoza Black Local Authority was staged in $1985 .{ }^{4}$ In response, the area came to be considered as ungovernable and a State of Emergency was declared - student and trade union leaders were harassed, assaulted and arrested, reducing the level of political activism until the 1990s.

\footnotetext{
4. $1 \mathrm{USD}=1.85$ South African Rand in 1985.
} 
Life continued to get more difficult for residents as schools were closed, criminal gangs emerged in the vacuum left by the arrest and detention of political and civic leaders. In the mid-1980s, the apartheid state embarked on a 'Great Sale' of township housing, based on a principle of 'buy your property or lose it'. In order to buy their plots, leaseholders pushed up the rents of tenants in backyard shacks or crammed in more shacks (Sapire, 1992). Conditions in the township worsened, until it was not uncommon for $11-15$ people to share 1 toilet and 150 people to share a tap. By 1987 , Thokoza was the most congested township on the East Rand because of the failure to provide additional land to accommodate the growing population and the financial demands placed on the original leaseholders. The congestion, deteriorating services and worsening living conditions resulted in constant conflict and tension caused by too few resources being shared by too many people.

In addition, the government failed to legitimate those formal property rights that it had allocated in Thokoza. While the township had been rezoned and the land could be subdivided (referred to as a process of proclamation) in 1958, title deeds were only finally and completely registered in the Deeds Office (referred to as the establishment of the township) 26 years later in 1984 under the Black Communities Development Act, No 4 of 1984. This provided for certain Black Africans holding rights under the 1945 Native (Urban Areas) Consolidation Act to be granted freehold ownership. The BCDA was repealed by the Abolition of Racially Based Land Measures Act No 108 of 1991 except for Annexure F, because the latter was the only legislation governing land use in townships (Oakenfull, 2008: Pers.comm.). Annexure F permits a wide range of activities and imposes no density or height restrictions on plots. Its continued use as the framework for managing land use and construction in townships appears to 
be a pragmatic acceptance by the post-1994 government and local authorities of the outcomes generated by years of relative neglect of conditions in townships such as Thokoza.

\section{Property rights as part of networks that transmit conflict from elsewhere}

The final example of why it is hazardous to take property rights for granted in considering urban land conflicts over property rights is to return to the consideration of how property rights are dependent on networks of agents, institutions, processes, documents and so on, for their validity and value. In this section, I present instances of how rental permits in hostels and backyard shacks, and informal ownership claims circulate in very different networks that can themselves transmit conflict from elsewhere.

As noted earlier, from the 1960 s onwards, permits were issued to entitle recipients to live in the single-sex hostels. These were similar in concept to standard tenancies of public housing, but provided less security. Their use can be seen as another elaboration of the government's divide-and-rule strategy. Not only were the permits issued only to men, they were different from (and regarded as inferior to) leaseholds. In addition, spaces in the hostels were allocated along ethnic, language and geographic lines, extending segregation practices to the micro-level. These allocation processes were endorsed by many migrants, who sought succour from the difficulties associated with migrant life and the brutalities of apartheid in their relationships with people with whom they had kinship and other links. 
The hostels were thus distinctive spaces in which social networks were linked to the rural origins of the migrants. In addition to the state's attempts to physically isolate migrant workers from township residents (in the name of conflict reduction), the research showed that migrants themselves drew heavily on their shared rural values, which they often perceived as superior and which they considered their township neighbours to lack. For example, older hostel dwellers, referred to as 'big brothers', sought to 'protect' newer residents from the 'corrupting' influences of urban township life. Young migrants were often mentored by more experienced migrants, who advised and guided newcomers, and monitored their behaviour, spending patterns and leisure time - all within a strict hierarchy of respect based on age, similar to that in rural South African societies. For example, Respondent 2, a long-time hostel dweller, remarked that "he [the big brother] would give you some of [your salary], and save the rest, but if they found that you take some money from your salary before the big brother has it, oh... my god you will be in big trouble. Such things made people disciplined and work for their families".

Thus, the social networks associated with hostels were heavily invested in maintaining rural linkages and identities, making them very much islands of imagined rurality in the heart of urban Thokoza. While rural values were important in the lives of many township dwellers (James, 2007), the hostels reinforced the government's preference for Black Africans to be only temporary urban residents, and their allocation practices reinforced ethnic and rural identities. Moreover, while the government owned and initially oversaw the running of the hostels and acted as if it was the only source of authority, it also made use of forms of authority, and conflicts associated with this authority, based on a customary rural institution. 
The authority figures were the izindunas (customary headmen in Zulu society), who controlled access to accommodation, the management of and transactions within the hostels. Although this leadership institution was derived from rural society, its authority was based on municipal endorsement and use as the government's informal but extremely powerful management arm. One of the headmen in the Thokoza hostel described his role as:

'... to resolve conflict among people, for example if there was a conflict between someone from Enqhuthu and someone from Emsinga ${ }^{5}$, I'd contact the person in charge at Emsinga to resolve the issue, then the person that is found to be guilty must apologise in the traditional way with a sheep or cow and even money. If it happens they kill each other, that's where I come in, I'd send a report to the king every year. I once sent cows to Emsinga from the Ntenga family....The problem must be resolved'.

Thus, access to and use of accommodation, the value and validity of the permit as a property right and mechanisms for resolving conflicts over land and other issues depended in part on social conflicts that worked over great distances, transmitting (although rarely without some distortions) social dynamics from rural to urban and urban to rural areas. In addition, they depended on complex interactions and interdependencies between formal (municipal) and informal or customary institutions (the izindunas), resulting in the emergence of a multi-nodal, multi-valent network of agents, processes and temporalities in which conflict could be transmitted through property rights.

\footnotetext{
5. Rural towns in Kwazulu-Natal province.
} 
Another example is that although the tenants holding informal tenancy rights in backyard shacks are tacitly accepted by the state, they are embedded in social networks different to those of the leaseholders on whose plots they live. Informal systems based on social networks have emerged to manage the space within plots. For example, reflecting on the process of finding somewhere to live, a male backyard tenant observed:

"The best thing is to network with people, ordinary people. If you are working, talk to people at work, or if you go to church, tell people, or if you go to the library, tell people that you are looking for a place to rent - they can help. Because you can't wake up in the morning and look for a place to stay by doing door-to-door. You won't find it." (Respondent 19, 2).

And finally, property rights in the informal settlements run through complex networks that include elements of the state and political parties. That is, in the informal settlements, ownership rights are not purely informal, since the local councillor's endorsement of transactions in land is required. For example, describing how she had obtained a plot in the informal settlement behind the hostels in 2000, Respondent 22 recounted how she had been shown a piece of land by the 'owner' and advised that she could occupy it and build a shack if she could produce an 'organisation card' that would prove that she was a card-carrying member of the IFP. Other respondents suggested that a political affiliation is no longer required to access land, although they reported that it is still necessary to make their request to a woman who is a local representative of the IFP. Reportedly, she, in conjunction with the formally elected municipal councillor, makes the decision on whether to grant an applicant access to a 
plot or to approve a land sale. There is thus a conflation of informal and formal allocation mechanisms. Satisfying these requirements might suggest that 'owners' in informal settlements have security, but at the time of the research, one resident reported that they had recently been told that they were to be evicted because the council wanted to build a stadium on the informally occupied area.

In sum, I have presented four examples of the ways in which different property rights were themselves the outcome of conflict, expressions of conflict, less protected from conflict or able to transmit conflict from elsewhere. In the concluding section, I consider what value this additional form of analysis adds to engaging with urban land conflict.

\section{Conclusion}

The aim of my argument has been to complement existing understandings of, engagements with, urban land conflicts that relate to property rights. There is certainly great value in engaging with urban land conflicts in terms of the peoples' struggles over property rights. In terms of a framework like the example provided by Wehrmann (2008), the analysis guides activists and scholars to assess the relative power and strengths of different parties to conflict and what interests might underpin and shape the conflict. This type of analysis cannot be done away with.

In conclusion, I highlight the added value of also assessing how property rights are already constituted by conflict and the two differences this makes. First, there are additional sources of conflict that are brought into view as processes and social interactions that can be engaged with by activists and scholars. Adding to the view of 
conflict between different parties, we also now have conflict that exists within property rights themselves. In the South African context and elsewhere, there is a tendency to take (particularly state-sanctioned) property rights as given, for analysis to focus on conflicts between those seeking land with such defined rights, and for policy and practice to focus on issuing or upgrading rights and claims where desirable or possible. However, based on an in-depth analysis of the history of a single precinct within a typical township in Johannesburg, I have argued that this focus is insufficient to understand and explain urban land conflicts that relate to property rights. Instead, analysis of urban land conflict should be extended beyond assessing the relative power of different parties struggling over property rights to land to consider wider causes and effects of conflict, including those inherent in different categories of property rights themselves. Such an improved understanding can lead to identification of a broader suite of interventions, which might be able to realise the progressive or ameliorate the regressive effects of conflict for the different parties involved.

Second, the conflict imbricated in property rights legitimates new forms of engagement in urban land conflict. This is because these forms of conflict are a reflection of underlying, structural inequalities that continue to disadvantage particular groups. Some of these emerge from historical inequalities and some of these arrive from elsewhere. In Thokoza, some of the struggles over property rights have supposedly been resolved, in that some residents have struggled over their inferior leaseholds and won the right to formal freehold property rights. However, conflicts over land rights continue. Some of those between residents and the state have not yet been resolved. Others rumble along at a low level. For example, the quality of freehold property rights in Thokoza is less than elsewhere in Johannesburg, 
partly because these property rights incorporate the outcomes of prior conflict. For example, freehold owners are unable to use their titles as collateral for loans from formal financial institutions. In addition, the infrastructure that adds value to their land is only provided at the 'basic' or 'minimum' level. Further, they attempt to make demands that cannot be met because the relevant organisations are part of a wider government system, the main focus and resources of which are diverted elsewhere. For example, they expect the local authority to improve infrastructure and services (which will enhance the value of their land), but it does not commit the necessary personnel and resources because it is focused on enforcing property rights in historically well-developed parts of the city.

This adds to the analysis gained from a framework like Wehrmann's (2008) where the underlying causes of conflict are traced to individual interests driven by fears and desires. It is not as easy to map conflict constituting property rights against individual interests and thus, sometimes inadvertently, perpetuate the idea that the only property rights that count are private property rights held by individuals and the reason they are so valued is because they are perceived to be free of conflict.

\section{References}

Anonymous. (2008) Interview. In: Rubin M (ed). City of Johannesburg.

Baskin J. (1993) Communities, conflict and negotiated development. Seminar No. 4. Johannesburg: Centre for the Study of Violence and Reconciliation.

Beall J, Goodfellow T and Rodgers D. (2011) Cites, conflict and state fragility. London: London School of Economics and Political Science.

Benda-Beckman Fv. (2002) Who's afraid of legal pluralism? Journal of legal pluralism 47: 37-82.

Beningfield J. (2006) The frightened land. Land, landscape and politics in South Africa in the Twentieth Century, London: Routledge.

Blomley N. (2004) Unsettling the city: Urban land and the politics of property, New York: Routledge. 
Bonner P and Nieftagodien N. (2001) Kathorus: A history, Cape Town: Maskew Miller Longman.

Bremner L. (1994) Development and resistance. Urban Forum 5: 23-44.

Gauteng Provincial Government. (2006) Housing to hand over Thokoza Title Deeds. Available at: http://www.gpg.gov.za/docs/pr/2006/pr0195.html.

GLTN. (2012) Handling land. Innovative tools for land governance and secure tenure, Nairobi: UN-Habitat, Global Land Tools Network and IIRR.

Hui ECM and Bao H. (2013) The logic behind conflicts in land acquisitions in contemporary China: A framework based upon game theory. Land Use Policy 30: 373-380.

James D. (2007) Gaining ground? 'Rights' and 'property' in South African land reform, Johannesburg: Wits University Press.

Kombe WJ. (2005) Land use dynamics in peri-urban areas and their implications on the urban growth and form: The case of Dar es Salaam, Tanzania. Habitat International 29: 113-136.

Kombe WJ. (2010) Land conflicts in Dar es Salaam: who gains? Who loses? Cities and fragile states. London: Crisis States Research Centre, London School of Economics and Political Science.

Lombard M. (2012) Land tenure and urban conflict: a review of the literature. Manchester: University of Manchester.

Macpherson CB. (1992) Property, mainstream and critical positions, Toronto: University of Toronto Press.

Marx C and Rubin M. (2008) Urban land biographies. A study of co-existing land use and land use management in three precincts in Gauteng. Pretoria: Urban LandMark.

McAuslan P. (2005) Legal pluralism as a policy option: is it desirable, is it doable? : UNDP-International Land Coalition.

Oakenfull L. (2008) Interview. In: Rubin M (ed). City of Johannesburg.

Obala LM and Mattingly M. (2013) Ethnicity, corruption and violence in urban land conflict in Kenya. Urban Studies 51: 2735-2751.

Rakodi C and Leduka RC. (2004) Informal land delivery processes and access to land for the poor: A comparative study of six African cities. International Development Department, University of Birmingham and Department of Geography, National University of Lesotho.

Sapire H. (1992) Politics and Protest in Shack Settlements of the PretoriaWitwatersrand-Vereeniging Region, South Africa, 1980-1990. Journal of Southern African Studies 18: 670-697.

Singer JW. (2000) Entitlement: The paradoxes of property, New Haven and London: Yale University Press.

Vermeulen GM. (1981) An urban design framework for the provision of facilities in urban Black townships, with particular reference to Kathlehong, Thokoza and Vosloorus. Johannesburg: University of the Witwatersrand, Faculty of Architecture.

Wehrmann B. (2008) Land conflicts. A practical guide to dealing with land disputes. Eschborn: Deutsche Gesellschaft fur Technische Zusammenarbeit (GTZ) $\mathrm{GmbH}$. 


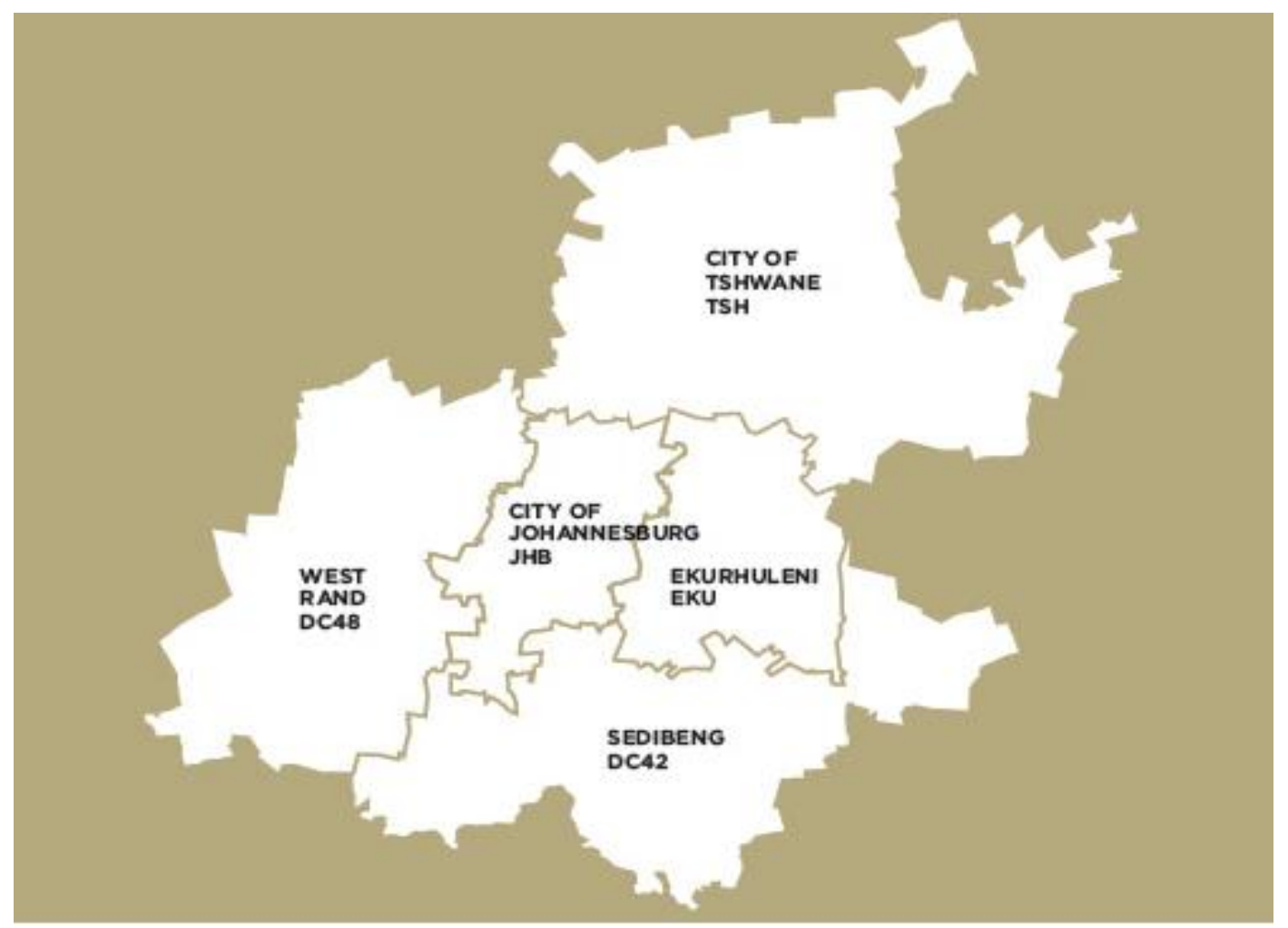

Figure 1. Location of Thokoza in Ekhuruleni, Gauteng Source: South Africa Yearbook 2012/13, published by the Government Communication and Information System 


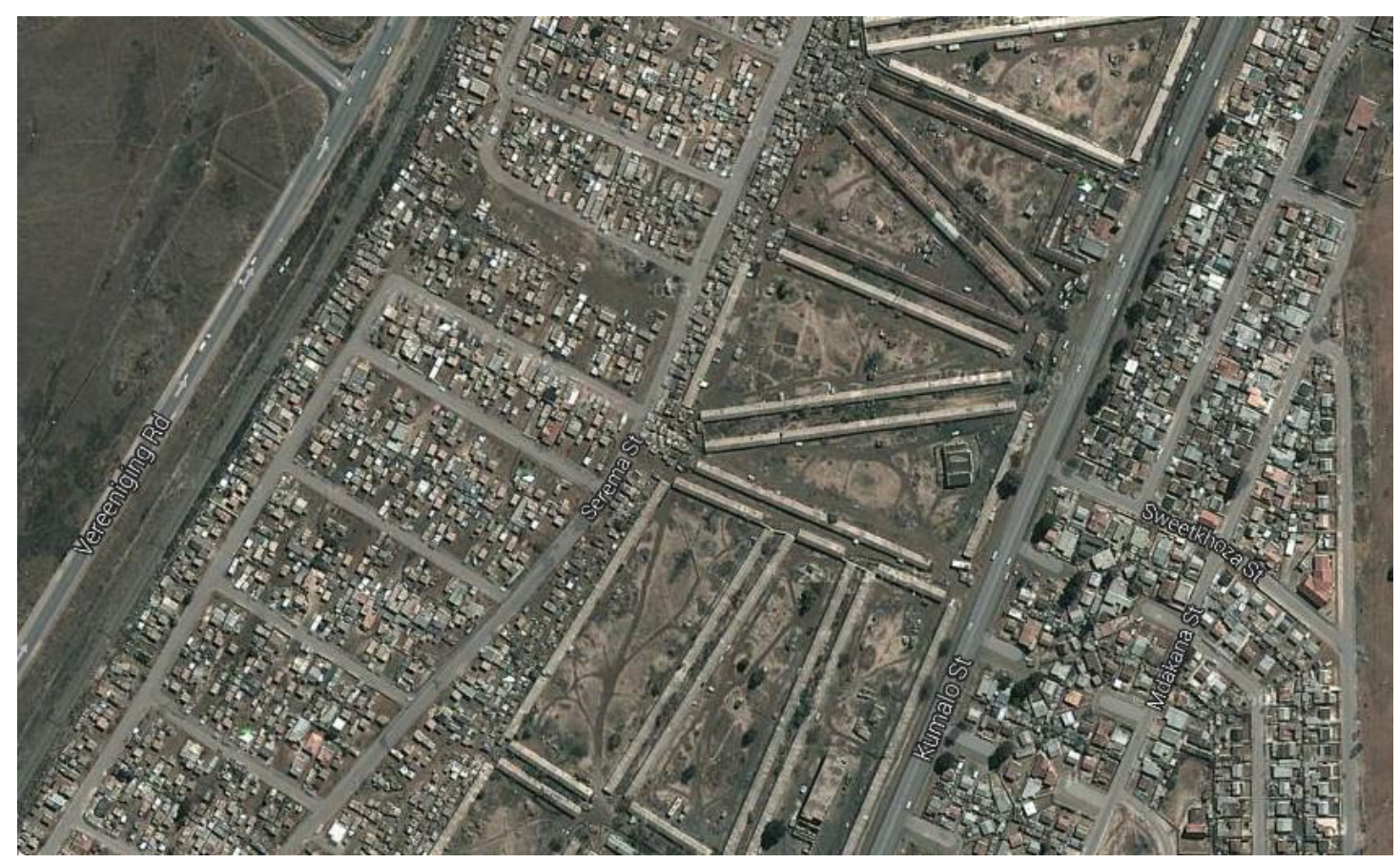

Figure 2. Precinct within Thokoza Source: Googlemaps: Digitalglobe 